\title{
Reproductive features of the eastern mole (Scalopus aquaticus) and star-nose mole (Condylura cristata)
}

\author{
J. M. Bedford ${ }^{1}$, O. B. Mock², S. K. Nagdas' ${ }^{3}$, V. P. Winfrey ${ }^{3}$ and G. E. Olson ${ }^{3}$ \\ ${ }^{1}$ Departments of Obstetrics and Gynecology, and Cell Biology and Anatomy, Weill Medical College at Cornell University, \\ New York, NY 10021, USA; ${ }^{2}$ Department of Anatomy, Kirksville College of Osteopathic Medicine, Kirksville, MO 63501, USA; \\ ${ }^{3}$ Department of Cell Biology, Vanderbilt University, Nashville, TN 37232, USA
}

\begin{abstract}
Since moles are closely related to shrews, the gametes and reproductive tracts of the star-nose mole (Condylura cristata) and the eastern mole (Scalopus aquaticus) were examined to gain further insight into unusual reproductive traits of the Soricidae. Moles display many of these soricid traits, but with some important differences. The cumulus oophorus of Scalopus, ovulated about $16 \mathrm{~h}$ after hCG injection, was largely dispersed by hyaluronidase and, though quite dense, was nevertheless more similar to that of higher mammals than to the compact 'ball' of the soricid cumulus. Within the female tract in these moles, approximately $85 \%$ of the length of the oviduct comprises a narrow ampulla with numerous differentiated crypts that, in shrews, house spermatozoa. However, in contrast to shrews, moles produce considerably larger numbers of spermatozoa, which challenges the proposal that, in shrews, oviductal sperm crypts specifically permit lower sperm production by the males. In the sperm head of these two moles, the acrosome displays the long rostrum that is typical of other Insectivora, and the perforatorium has the barbs by which soricid spermatozoa probably bind to the zona pellucida. Perhaps allied to this, immunoblots indicated that the immunoreactive acrosomal matrix of Scalopus spermatozoa is simpler than the polypeptide complex of the bovine and hamster acrosomal matrix.
\end{abstract}

\section{Introduction}

Despite intensive studies of mammalian gametes over the last three decades, major features of the structure of mammalian spermatozoa, and their interactions with both the male and female reproductive tracts and with the egg, remain to be elucidated (Bedford, 1991). As a wider comparative perspective might offer some further insights in this regard, the focus of our recent work has been gamete structure and function among the Insectivora. This order, which is also designated in evolutionary literature as Lipotyphla, has many primitive eutherian features, and is generally considered to comprise shrews, moles, hedgehogs, golden moles, tenrecs and solenodons (McKenna and Bell, 1997).

Although insectivores are of special interest because of their apparent proximity to the ancestors of living mammals, there is a paucity of information about the gametes of this group (Hayssen et al., 1993). Recently, it has proved possible in five different shrew genera to examine the structure and behaviour of their gametes, and, in some cases, the events of fertilization (for references, see Bedford et al., 1998). However, rather than answering some of the broader questions about mammalian gametes, shrews display

Received 8 February 1999 reproductive features which, at present, only complicate the eutherian picture as a whole. These involve unusual features of spermatozoa, the organization of the male tract, the distribution of spermatozoa in crypts within the oviduct, and species-variable behaviour of the unusual compact cumulus oophorus. Unlike the situation in most placental mammals, the cumulus oophorus seems to be critical for fertilization in these small insectivores (Bedford et al., 1997a); spermatozoa appear to react and lose the acrosomal contents within the cumulus, with binding to the zona pellucida by way of barbs on the exposed perforatorium (Bedford et al., 1997b).

It is not clear whether such soricid reproductive traits reflect the early stages of eutherian evolution, and so are 'primitive' forerunners of the situation seen now in most higher eutherian mammals, or whether they are derived features that have an adaptive significance particular to the Soricidae and, if so, what that might be. Therefore, we have begun to examine other Insectivora where possible, with a focus on the degree to which their gametes display the novel characteristics shown by those of shrews. Phylogenetically and taxonomically, the Insectivora have been one of the least stable eutherian groups and it has been suggested, on the basis of mitochondrial and nuclear DNA sequence data, that golden moles (chrysochlorids) and tenrecs are part of an 'African' clade together with the hyrax, the elephant shrew and the aardvark (Springer et al., 1997; Stanhope et al., 1998). 
However, although hedgehogs are generally grouped in the Erinaceomorpha as a separate suborder of the Insectivora, talpids (true moles) are always clustered with shrews. Some moles in the subfamiles Talpinae and Uropsilinae (shrewmoles), are superficially shrew-like, and shrews and moles are classified within one suborder (Soricomorpha) within the Lipotyphla. Thus, moles present as natural first subjects in attempting to gain further perspective on the novel reproductive features of the Soricidae. In the present study, two New World moles from different habitats were examined, the eastern mole (Scalopus aquaticus) and the starnose mole (Condylura cristata). The particular focus of the study was the extent to which their gametes and related features of the reproductive tracts diverge from those observed in shrews.

\section{Materials and Methods}

\section{Animals}

Male and female star-nose moles (Condylura cristata), weighing approximately $40-55 \mathrm{~g}$, were collected during the breeding season from late February to mid-April in southwest Potter County, Pennsylvania (Catania, 1995). The animals were caught in frequently monitored Sherman traps positioned within mole runs alongside shallow ponds or other wet areas. Eastern moles (Scalopus aquaticus), weighing approximately $70-80 \mathrm{~g}$ (females) and approximately $100 \mathrm{~g}$ (males), were collected during the breeding season in midFebruary from tunnels in relatively dry habitat in Nashville, Tennessee. Animals were killed soon after collection with an overdose of sodium pentobarbital administered i.p. or with $\mathrm{CO}_{2}$. Additional males, weighing $120-130 \mathrm{~g}$, were caught in March-April in spear traps in Boone County, Missouri, and were frozen at $-20^{\circ} \mathrm{C}$ until used for counts of the number of epididymal spermatozoa.

\section{Tissues}

Female. In two female Condylura, the Fallopian tubes and ovaries were dissected free of membranes and fixed in Bouin's solution. These organs were removed from two additional females first perfused with $4 \% \quad(\mathrm{v} / \mathrm{v})$ paraformaldehyde in $0.1 \mathrm{~mol}$ phosphate buffer $1^{-1}$. The organs were embedded, sectioned and stained with haematoxylin and eosin for light microscopy. In the case of Scalopus, three females were injected s.c. with $100 \mathrm{iu} \mathrm{hCG}$ to induce ovulation, and were killed $15-18 \mathrm{~h}$ later with $\mathrm{CO}_{2}$. Ovaries were mounted on wax-spot slides and examined with dissecting and phase-contrast microscopes for evidence of ovulation. Cumulus-oocyte complexes recovered from the upper oviduct or from the surface of ovulating follicles were mounted on wax-spot slides in $1 \%(\mathrm{w} / \mathrm{v})$ hyaluronidase (bovine type IV; Sigma, St Louis, MO) in medium 199 (M199) with Earle's salts (GIBCO BRL, Grand Islnad, NY) and observed by phase-contrast microscopy for evidence of cumulus disintegration. The oviducts were dissected free of mesosalpinx, mounted on wax-spot slides and, after slight flattening beneath a cover glass, the internal organization was studied by differential interference contrast microscopy.

Male. In both Condylura cristata and Scalopus aquaticus, the male reproductive tract and penis were excised and examined, and the testes were dissected from the epididymides and weighed. After stripping and thoroughly mincing the epididymis in M199, total counts were made with a haemocytometer of the spermatozoa released from the cauda epididymidis and caput and corpus epididymides, respectively. For studies of sperm ultrastructure, small pieces of cauda epididymidis were fixed in $2 \%(\mathrm{v} / \mathrm{v})$ glutaraldehyde in $0.1 \mathrm{~mol}$ cacodylate buffer $\mathrm{l}^{-1}$, post-fixed in aqueous $1 \%$ osmium $: 1.5 \%$ potassium ferricynaide $(\mathrm{w} / \mathrm{v})$, dehydrated in alcohols, propylene oxide or acetone, and embedded in Polybed 812 (Polysciences, Warrington, PA).

The acrosomal matrix was analysed in spermatozoa from the cauda epididymidis of Scalopus aquaticus. A sperm suspension of known concentration was centrifuged at $100 \mathrm{~g}$ for $5 \mathrm{~min}$ and resuspended for $30 \mathrm{~min}$ in $0.1 \%(\mathrm{w} / \mathrm{v})$ TritonX100 in Tris-saline inhibitor solution $\left(150 \mathrm{mmol} \mathrm{NaCl} \mathrm{l}^{-1}\right.$, $25 \mathrm{mmol}^{\text {Tris- }} \mathrm{HCl}^{-1}, \mathrm{pH} 7.5,2$ mmol benzamidine $\mathrm{l}^{-1}, 1 \mu \mathrm{g}$ pepstatin $\mathrm{ml}^{-1}$ and $1 \mu \mathrm{m}$ leupeptin $\mathrm{ml}^{-1}$ ). The protein concentration of whole spermatozoa was determined by the method of Bradford (1976). The suspension was centrifuged at $12000 \mathrm{~g}$ for $5 \mathrm{~min}$ at $4^{\circ} \mathrm{C}$; the supernatant was saved and the pellet was resuspended in an equivalent volume of extraction solution.

For western blotting, samples of whole spermatozoa solubilized at $95^{\circ} \mathrm{C}$ for $3-5 \mathrm{~min}$ in SDS-dithiothreitol (DTT) were run on a $12 \%$ SDS-PAGE gel (Laemmli, 1970). Polypeptides were transferred to polyvinylidene fluoride (PVDF) membranes (Towbin and Gordon, 1984) and incubated in a blocking solution of PBS (150 mmol $\mathrm{NaCl} \mathrm{l}^{-1}$, 20 mmol $\mathrm{Na}_{2} \mathrm{PO}_{4} \mathrm{l}^{-1}, \mathrm{pH} 7.6$ ) containing $0.1 \%(\mathrm{w} / \mathrm{v})$ Tween 20 , $5 \%$ goat serum, $5 \%(\mathrm{w} / \mathrm{v})$ non-fat dry milk and $2.5 \%$ BSA. Membranes were then incubated in primary serum diluted in PBS containing 1\% goat serum (PBS-GS); the two antisera used were prepared against a $32 \mathrm{kDa}$ polypeptide of bovine acrosomal matrix (Olson et al., 1997) and a $22 \mathrm{kDa}$ polypeptide of hamster acrosomal matrix (Olson et al., 1998), respectively. Both antisera recognize the same sets of homologous polypeptides in each species. Parallel control blots were exposed to pre-immune or non-immune serum. After three rinses in PBS-GS, the blots were incubated for $1 \mathrm{~h}$ at room temperature in an affinity-purified peroxidaseconjugated secondary antibody (Jackson ImmunoResearch, Park Grove, PA) and, after further rinses, immunoreactive bands were developed using diaminobenzidine and $\mathrm{H}_{2} \mathrm{O}_{2}$.

Scalopus aquaticus spermatozoa were immunostained using the bovine and hamster acrosomal matrix antisera (Olson et al., 1997, 1998) according to one of two different regimens. The spermatozoa were suspended in $0.1 \%(\mathrm{w} / \mathrm{v})$ Triton-X100 in Tris-saline inhibitor solution for $30 \mathrm{~min}$ at $4{ }^{\circ} \mathrm{C}$, or were first fixed for $30 \mathrm{~min}$ in $4 \%(\mathrm{v} / \mathrm{v})$ formaldehyde in $0.1 \mathrm{~mol} \mathrm{Na}_{2} \mathrm{PO}_{4} \mathrm{l}^{-1}$ buffer and permeabilized for $30 \mathrm{~min}$ in fixative containing $0.25 \%(\mathrm{w} / \mathrm{v})$ Triton-X100. Spermatozoa attached to poly-L-lysine-coated coverslips were incubated for $10 \mathrm{~min}$ at $-20^{\circ} \mathrm{C}$ in acetone, air dried, and incubated in a 
blocking solution of $5 \%$ donkey serum and 2.5\% BSA in Tris-saline (150 mmol NaCl 1-1 25 mmol Tris- $\mathrm{HCl} \mathrm{l}^{-1}, \mathrm{pH} 8.0$, and $0.05 \%(\mathrm{w} / \mathrm{v})$ Tween 20$)$, before exposure to immune serum or an equivalent dilution of pre-immune serum in blocking solution. After three rinses in Tris-saline with 1\% donkey serum, the spermatozoa on coverslips were incubated for $1 \mathrm{~h}$ at room temperature in indocarbocyanine (Cy3)-conjugated affinity-purified secondary antibody (Jackson ImmunoResearch) diluted in blocking solution. After incubation, the coverslips were rinsed several times in Tris-saline and the spermatozoa were examined by phasecontrast and epifluorescent microscopy.

\section{Results}

\section{Male reproductive tract}

In both moles, the extruded penis was relatively large but could be distinguished morphologically according to species. The broad penis of Scalopus was covered with rows of backward facing spines, which were not present towards the meatus (Fig. 1). The narrower barrel of the Condylura penis terminated in a relatively enlarged glans reminiscent of an arrowhead, and was also covered with spines.

The testes were abdominal in both species, and the cauda epididymidis extended posteriorly into a cremaster sac on either side of the rectum. The testes were relatively large compared with the size of the animals. The mass of the testis was greater in the smaller species, Condylura, both absolutely and particularly as a function of body weight (Table 1). The number of spermatozoa in the epididymides and vasa deferentia was correspondingly higher; more than $3 \times 10^{9}$ were present in two of the three Condylura males. The vas deferens epithelium in both species was marked by regular corrugations or pockets throughout its length (Fig. 2).

\section{Spermatozoa}

Morphology. In both species of New World mole, the morphology and ultrastructure of the spermatozoa resemble that of the European mole (Suzuki and Racey, 1976; Castellani-Ceresa et al., 1980). A rostral extension of the

Table 1. Characteristics of the male reproductive tract in the eastern mole, Scalopus aquaticus, and the star-nose mole, Condylura cristata

\begin{tabular}{|c|c|c|}
\hline & $\begin{array}{c}\text { Scalopus } \\
(n=5)\end{array}$ & $\begin{array}{c}\text { Contylura } \\
(n=3)\end{array}$ \\
\hline Body weight (g) & $87-131^{\prime \prime}$ & $45-52$ \\
\hline Testis mass $(\mathrm{g})$ & $0.73-0.94$ & $0.95-1.15$ \\
\hline \multicolumn{3}{|l|}{ Number of epididymal spermatozoa $\left(\times 10^{6}\right)^{b}$} \\
\hline Caput and corpus epididymides & $36-48$ & $156-200$ \\
\hline Cauda epididymidis and vas deferens & $532-610$ & $1780-3122$ \\
\hline
\end{tabular}

"Range.

"Totals in both sides of the male tract.

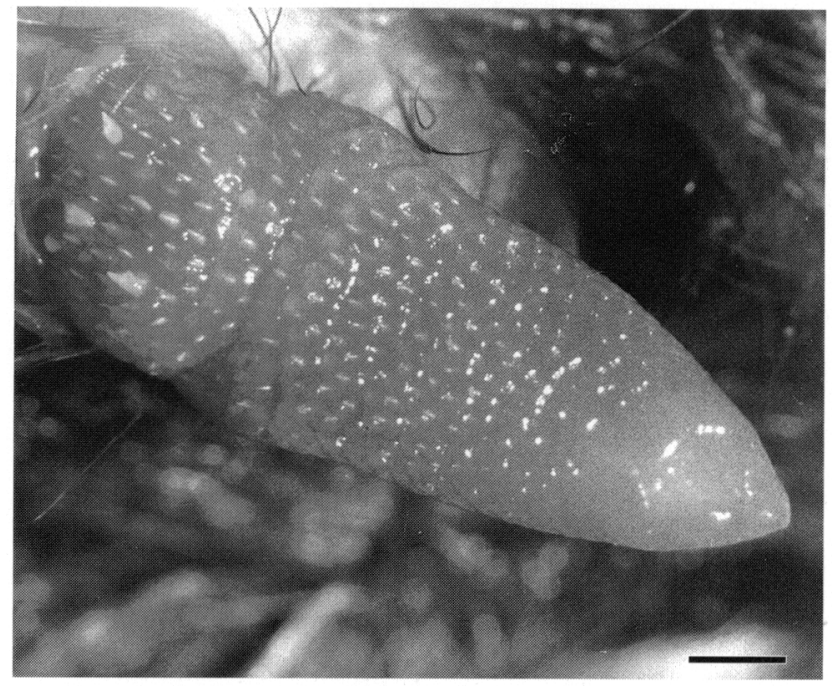

Fig. 1. Extruded penis of eastern mole, Scalopus aquaticus. The barrelshaped form of the penis complements the broad dimensions of the vagina in this species. Other than the region around the external meatus, the surface of the penis is covered with posteriorly directed spines. Scale bar represents $1.65 \mathrm{~mm}$.

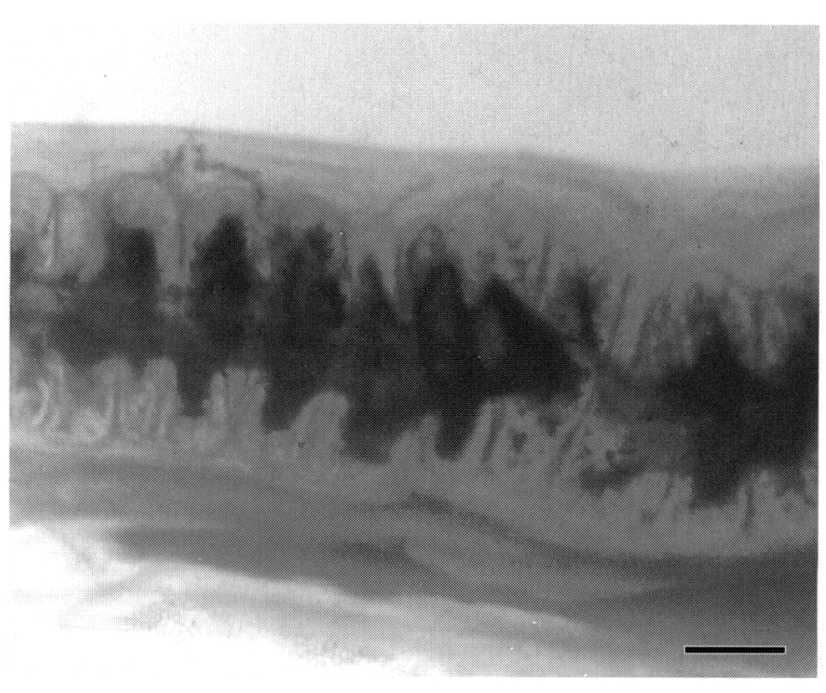

Fig. 2. Segment of a whole mount of unfixed vas deferens from eastern mole, Scalopus aquaticus, slightly flattened by a coverslip and viewed under differential interference contrast microscopy. The vas epithelium is arranged, unusually, as a series of folds. Scale bar represents $0.6 \mathrm{~mm}$.

acrosome extends significantly beyond, and in the midsagittal plane is longer than, the nucleus (Fig. 3), and a bipartite dense fibre 1 gives a bilateral symmetry to the tail. An additional feature not previously mentioned is the form of the perforatorium, which displays an inner layer distinguished from the perinuclear matrix within the projection of the inner acrosomal membrane (Fig. 4). Although the perforatorium appears as a simple extension in 


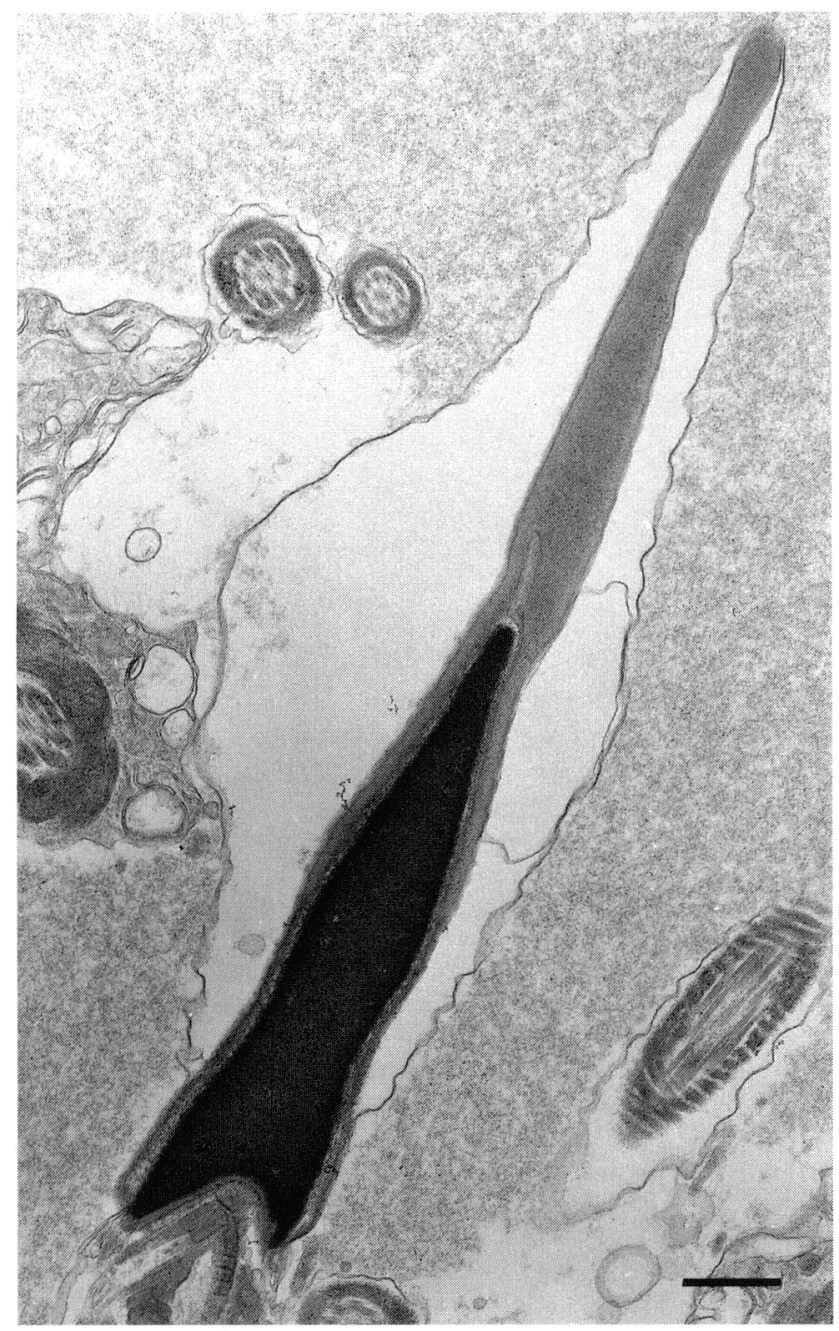

Fig. 3. Quasi-midsagittal transmission electron micrograph section of the head of a spermatozoon in the cauda epididymidis of the starnose mole, Condylura cristata. At its central point, the rostral extension of the acrosome actually occupies 0.6 and the nucleus 0.4 of the total length of the sperm head. Scale bar represents $0.5 \mu \mathrm{m}$.

mid-sagittal sections of the head, in parasagittal sections this extension is often interrupted (Fig. 5). As indicated in this study (Fig. 6) and by similar studies on the spermatozoa of shrews (Phillips and Bedford, 1985), fruit bats (Rouse and Robson, 1986) and elephant shrews (Woodall, 1991), the latter reflects a barbed configuration of the perforatorium.

Acrosomal matrix. Scalopus spermatozoa were extracted with Triton-X100 and examined by phase-contrast microscopy and immunostaining to determine whether moles have a detergent-stable acrosomal matrix, as in hamsters and bulls (Olson et al., 1997, 1998). Detergent-stable acrosome caps were observed either still associated with, or detached from, the sperm head. Antisera to the hamster and bovine acrosomal matrix resulted in specific immunofluorescent staining of these acrosomes (Fig. 7b), while the equatorial segment and all other sperm structures

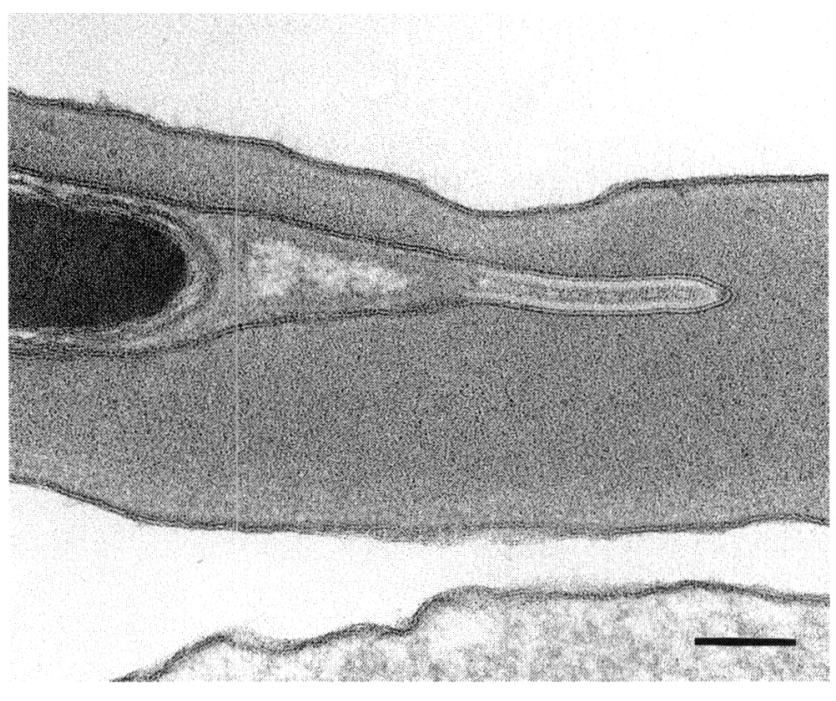

Fig. 4. Transmission electron micrograph of the apex of the nucleus and the perforatorium extending from it, in an epididymal spermatozoon of the star-nose mole, Condylura cristata. In this midsagittal section, the perforatorium is typically continuous or uninterrupted. Scale bar represents $0.1 \mu \mathrm{m}$.

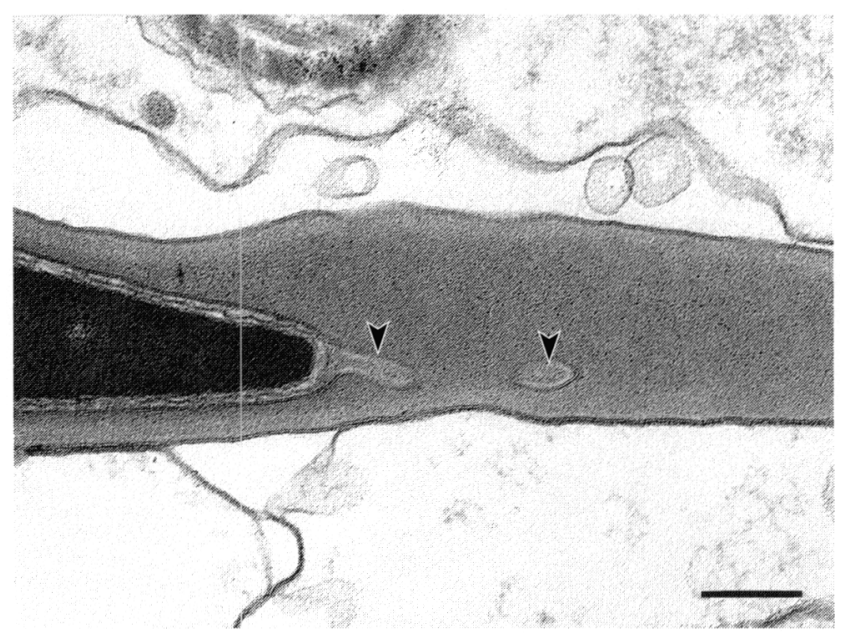

Fig. 5. Transmission electron micrograph of a parasagittal section through the apex of the sperm nucleus and the perforatorium of the star-nose mole, Condylura cristata. The interrupted form of the perforatorium, which presents as two apparently separated segments (arrowheads), reflects the fact that the section passes more laterally through a barb of the perforatorium, as depicted in Fig. 6. Scale bar represents $0.2 \mu \mathrm{m}$.

were unstained. Detached acrosomes showed positive immunostaining (Fig. 7b, arrow), whereas spermatozoa in which the acrosome cap was not visible (Fig. $7 \mathrm{~b}$, arrowhead) showed no fluorescence over the anterior head. In additon, spermatozoa stained with pre-immune serum did not show any fluorescence. These observations demonstrate that the acrosome of mole spermatozoa fails to disintegrate in Triton$\mathrm{X} 100$, and contains a polypeptide that is antigenically related 


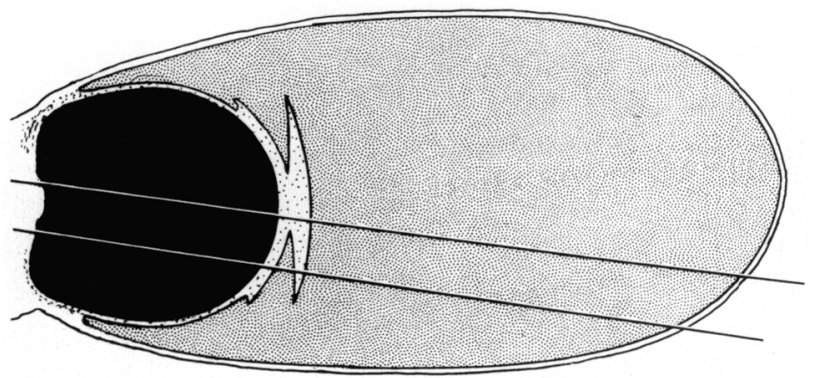

Fig. 6. Diagram of a sperm head of the star-nose mole, Condylura cristata, to show the approximate angle of sections in Figs 3,4 and 5, as related to the likely form of the perforatorium.
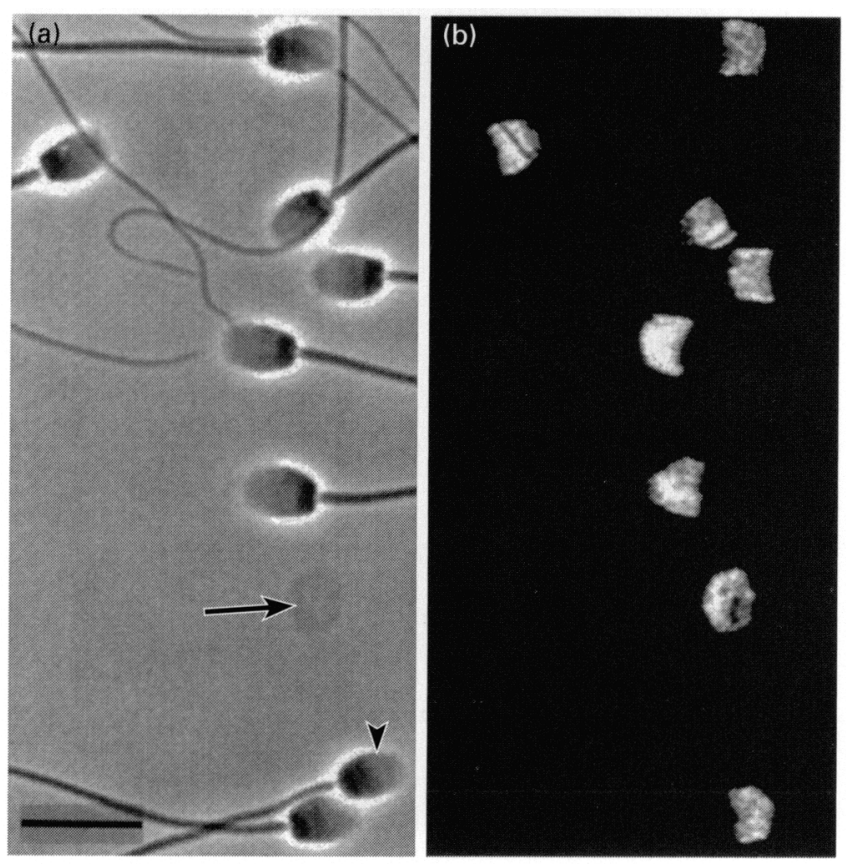

Fig. 7. Matched (a) phase-contrast and (b) fluorescence photomicrograph images of eastern mole, Scalopus aquaticus, spermatozoa from the cauda epididymidis, suspended in $0.1 \%(\mathrm{w} / \mathrm{v})$ Triton-X100 and stained with antiserum prepared against bovine sperm $32 \mathrm{kDa}$ acrosomal matrix polypeptide. Spermatozoa show intense fluorescence over the anterior acrosome, whereas the postacrosomal segment and flagellum are negative. Occasional spermatozoa that are unstained (arrowhead) have presumably lost the acrosomal cap since detached acrosomal caps (arrow) retain intense fluorescent staining. Scale bar represents $10 \mu \mathrm{m}$.

to the acrosomal matrix complex of hamster and bovine spermatozoa.

Immunoblot analysis was used to compare the composition of the acrosomal matrix polypeptide component in Scalopus spermatozoa with that of hamster and bovine spermatozoa (Fig. 8). When the antiserum against the $32 \mathrm{kDa}$ bovine matrix polypeptide was used, total lysates of mole spermatozoa showed specific staining of a major band of $26 \mathrm{kDa}$ and a minor band of $38 \mathrm{kDa}$ (Fig. 8, lane 1). When

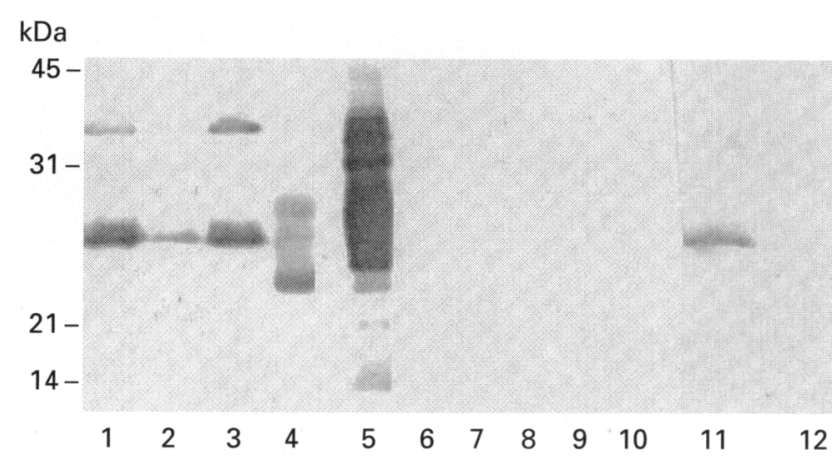

Fig. 8. Immunoblots showing the total (lanes 1 and 6), Triton- $X 100$ soluble (lanes 2 and 7), and Triton-X100 insoluble (lanes 3 and 8 ) polypeptides obtained from $2 \times 10^{6}$ eastern mole, Scalopus aquaticus, spermatozoa. Lanes 4 and 9 contain $13 \mu \mathrm{g}$ of a hamster acrosomal matrix fraction, and lanes 5 and 10 contain $10 \mu \mathrm{g}$ of a bovine sperm acrosomal matrix fraction. Lanes 1-5 were immunostained with an antiserum to bovine $32 \mathrm{kDa}$ acrosomal matrix polypeptide, and the duplicate control lanes $(6-10)$ were immunostained with preimmune serum at the same dilution. Lanes 11 and 12 contain $45 \mu \mathrm{g}$ protein from cauda epididymal sperm lysates. Lane 11 was immunostained with antiserum to the hamster $22 \mathrm{kDa}$ acrosomal matrix polypeptide, and lane 12 was treated with an identical dilution of non-immune serum.

mole spermatozoa were extracted by Triton-X100 alone, only a small amount of the $26 \mathrm{kDa}$ polypeptide was present in the supernatant (Fig. 8, lane 2). Most of the polypeptide was retained in the pellet along with the $38 \mathrm{kDa}$ component (Fig. 8 , lane 3), indicating that these components are relatively insoluble. Total lysates of mole spermatozoa immunostained with antibody against hamster acrosomal matrix (antiAM22) showed a single positive band of $26 \mathrm{kDa}$ (Fig. 8, lane 11); no bands in the controls stained with pre-immune (Fig. 8 , lanes 6-10) or with non-immune serum (Fig. 8, lane 12). In contrast, purified acrosomal matrix fractions of hamster (Fig. 8 , lane 4) and bovine spermatozoa (Fig. 8, lane 5) showed complex patterns of immunologically related polypeptides, as reported by Olson et al. $(1997,1998)$.

\section{Female reproductive tract}

In both mole species, the female tract comprised a relatively large vagina, a single cervix, and paired uterine horns that join and communicate close to the cervix. The ovary is surrounded by a bursa, which extends to the oviduct, and the ovarian end of the oviduct projects into the bursa. The dissected oviduct of Scalopus measured $2.2 \mathrm{~cm}$ in length in a $70 \mathrm{~g}$ non-pregnant female (Fig. 9) and $3.3 \mathrm{~cm}$ in a $74 \mathrm{~g}$ female with fetuses of $1 \mathrm{~cm}$ in length (nose-rump); the oviduct of Condylura was comparable. In both species, the isthmus occupied only approximately one-seventh of the total length of the oviduct, and was a short simple tube (Fig. 9). In contrast, the wall of the relatively narrow ampulla revealed a continuous array of differentiated epithelial crypts, clearly evident in living material examined with 


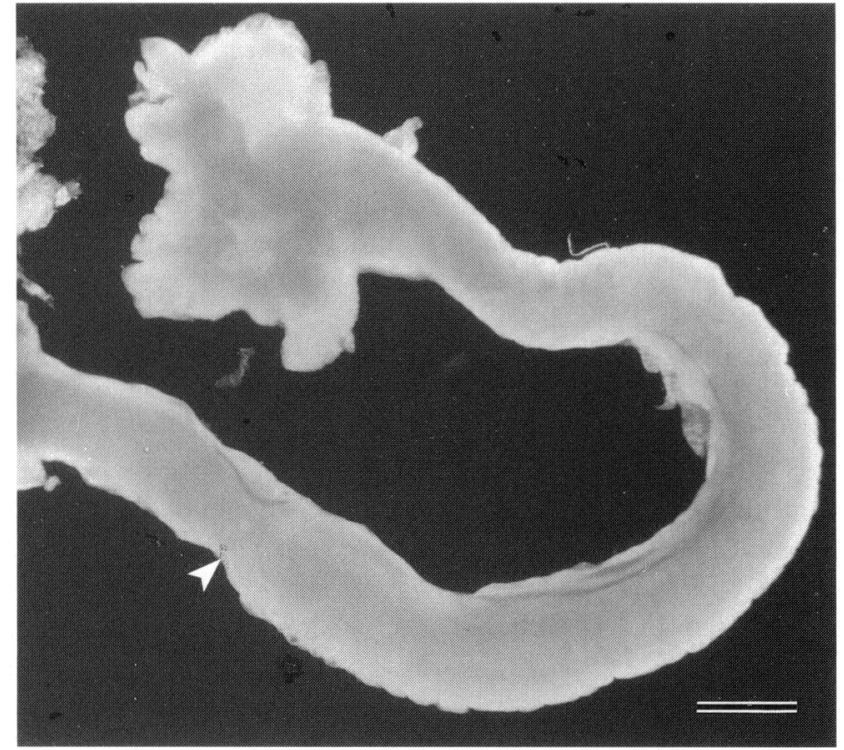

Fig. 9. Fallopian tube of eastern mole, Salopus nunaticus, dissected free of mesosalpinx and ovary. The tube is characterized by a short isthmus and by a relatively long narrow ampulla. The arrowhead denotes the approximate level of the isthmo-ampullary junction. Scale bar represents $0.12 \mathrm{~cm}$.

differential interference contrast microscopy (Fig. 10), and in histological sections of the ampulla. Many crypts displayed cells with active cilia, and some crypts housed groups of what appeared to be leucocytes.

The ovarian follicles were arrayed conventionally throughout the ovary of Scalopus. However, as in the European mole (Matthews, 1935; Deanesly, 1966), the follicles in the ovary of Condylurn were confined to one of the poles (Mossman and Duke, 1973), and the remainder of the organ was occupied by steroid-secreting interstitial tissue. In both species of mole, the cumulus oophorus appeared rather 'unshrew-like' in histological sections. It was peripheraily irregular, the cells were somewhat less closely apposed to one another, and there was some evidence of cumulus matrix between them. This impression was confirmed by the eggs ovulated after hCG injection in Scalopus. A non-pregnant female killed at $16 \mathrm{~h}$ after hCG, had three ovulated cumulus-oocyte complexes (right: 1, left: 2) that were still adherent to the ovarian surface at ovulation (Fig. 11). The cumulus was partly dispersed by incubation in $1 \%(\mathrm{w} / \mathrm{v})$ hyaluronidase (Fig. 12). A second female killed $18 \mathrm{~h}$ after hCG injection proved to be in mid- to late pregnancy, with three $1 \mathrm{~cm}$ fetuses that had fully formed limbs. In this female, there were two recent ovulation stigmata on the right ovary, and two eggs at metaphase II were extruded in full cumulus from the upper right oviduct. Again, much of the cumulus had disintegrated within about $10 \mathrm{~min}$ in $1 \%(\mathrm{w} / \mathrm{v})$ hyaluronidase, but the inner layers of cells remained intact. A third female had corpora lutea and in each uterine horn there were two implantation sites containing very small embryos in the preliminary limb bud stage. This early pregnant female displayed no ovarian stimulation $16 \mathrm{~h}$ after injection of hCG.

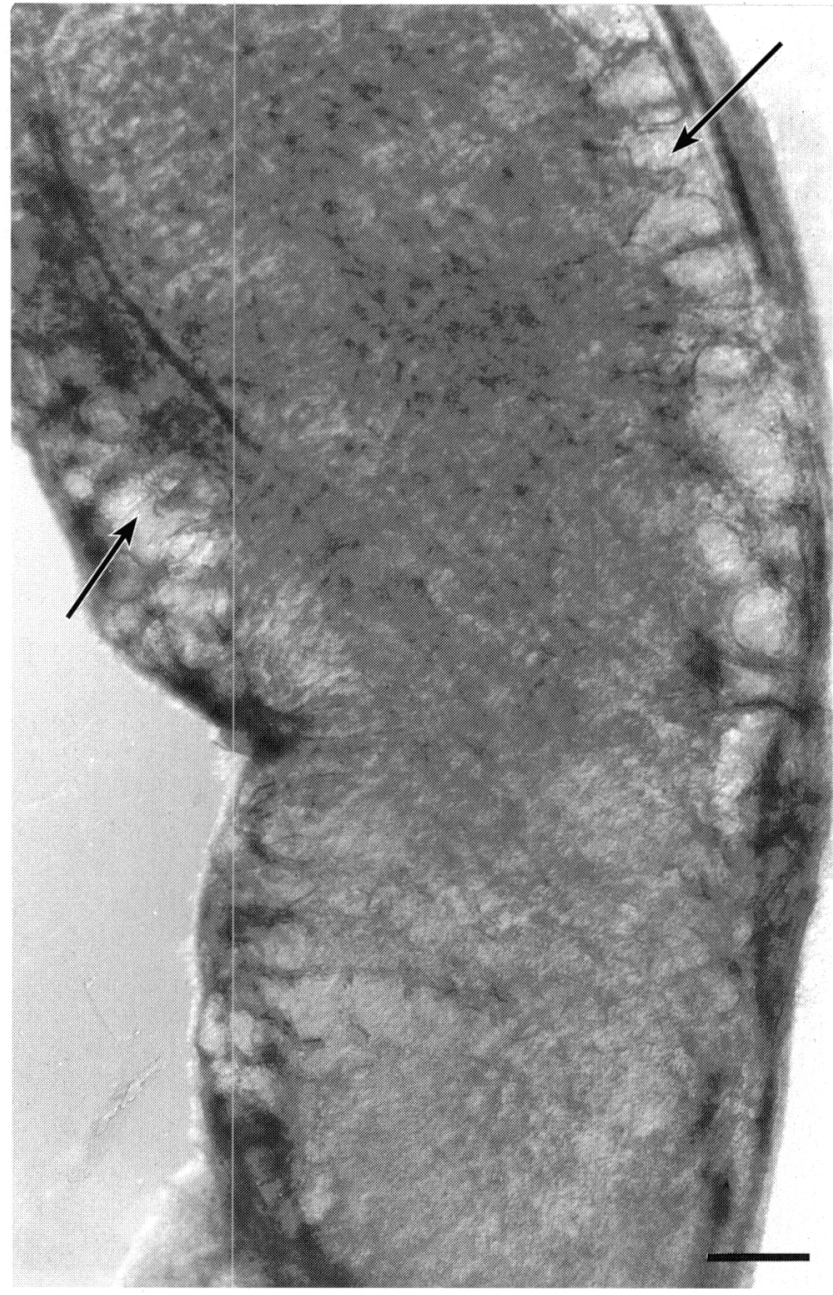

Fig. 10. Isthmo-ampullary junction region of an unfixed Fallopian tube from an unmated eastern mole, Scalopus aquaticus, under differential interference contrast microscopy. Slight flattening of the tissue reveals peripheral differentiated crypts (arrows), identical to those in soricine shrews. These crypts extend throughout most of the ampulla, show ciliated cells, and some house what appear to be groups of leucocytes. Scale bar represents $0.02 \mathrm{~cm}$.

\section{Discussion}

Unusual reproductive features recorded for moles, and not seen in soricids, include a vagina sealed for much of the year until the appearance of antral follicles. Furthermore, in some species, for example Talpa (Matthews, 1935; Deanesly, 1966) and, as shown in the present study, Condylura but not Scalopus, the follicles are concentrated at one ovarian pole; the remainder of the ovary consists of an interstitial gland of steroid-secreting cells interspersed by islets or tubular elements. The latter is considered by some to represent an ovotestis and in Talpa europaea its seasonal enlargement is correlated with higher concentrations of plasma testosterone (Whitworth et al., 1999).

This present survey of two species of mole was conducted primarily to gain further perspective on a number of 


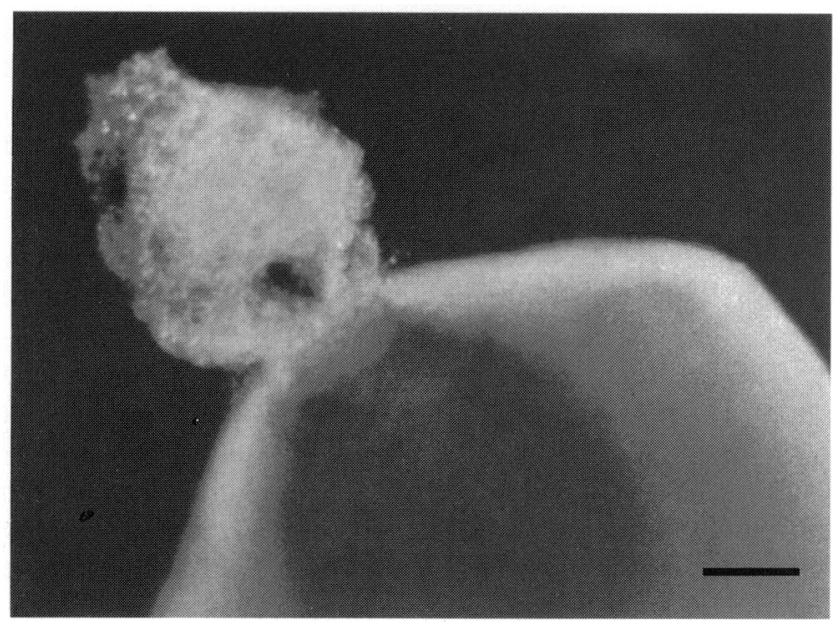

Fig. 11. Portion of ovulating ovary from a female eastern mole, Scalopus aquaticus, $16 \mathrm{~h}$ after administration of hCG. Much of the ovulating cumulus is quite dense. However, in contrast to the discrete cumulus ball ovulated by shrews, the mole cumulus was typically irregular in outline and, as shown here, remained attached to the stigma for a period of time. Scale bar represents $0.23 \mathrm{~mm}$.

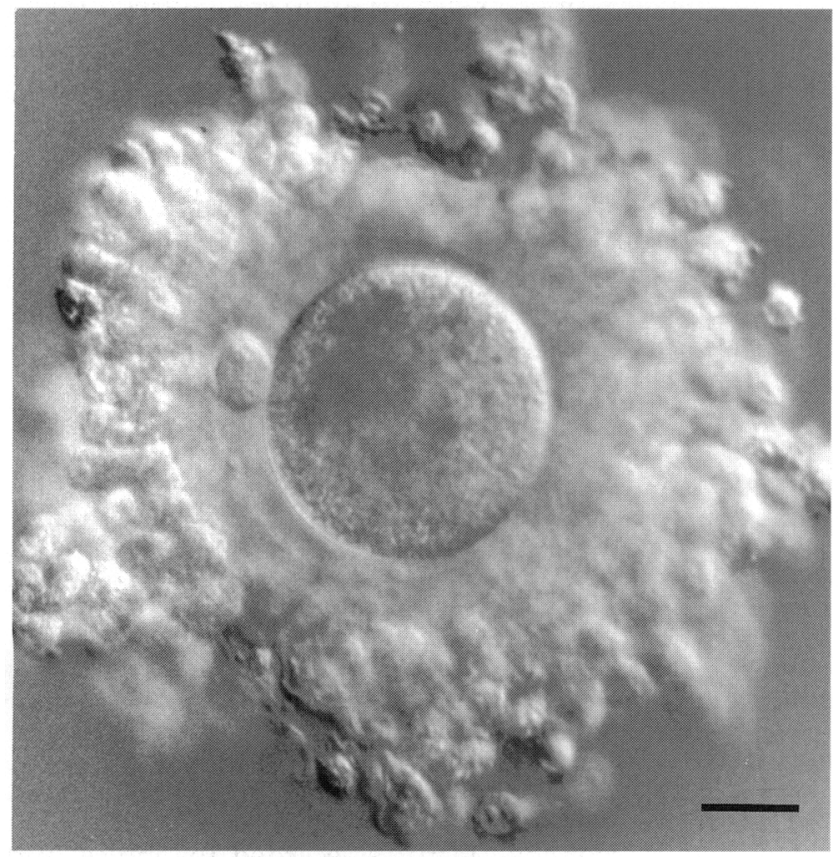

Fig. 12. Photomicrograph of the typical outcome of exposing the freshly ovulated cumulus-oocyte complex of the eastern mole, Scalopus aquaticus, to $1 \%(\mathrm{w} / \mathrm{v})$ hyaluronidase (compare with Fig. 11). Although hyaluronidase dispersed most of the cumulus, the periovular layers of cumulus cells were resistant. Scale bar represents $30 \mu \mathrm{m}$.

puzzling reproductive features observed in shrews. With the exception of their ovarian anatomy, Scalopus and Condylura both have similar reproductive features and also display many of the unusual reproductive traits of shrews, but with some important differences. Among the main points of interest are the form of the perforatorium of the sperm head, the particular character of the acrosomal matrix, the character of the cumulus oophorus, the organization of the Fallopian tube, and a large disparity between moles and shrews in the number of spermatozoa produced.

The reproductive system of the male mole is distinguished by testes that lie within the lower abdomen and by an unusually large number of spermatozoa stored in the epididymis (Racey, 1978). In the present study, the mass of the large testes in Condylura reached about $4 \%$ of body weight, but in one animal recorded by Hamilton (1931), the combined mass of the testes of $4.8 \mathrm{~g}$ amounted to $>8 \%$ of body weight, which is among the highest percentages recorded for mammals (Kenagy and Trombulak, 1986). Since in Talpa at least, the testis mass remains at a maximum for only a short time of about 1 month (Racey, 1978), this may partly account for such variation. Secondly, in most moles, including Scalopus and Condylura, formation of the copulation plug generally involves a different male accessory gland combination than that in shrews. All shrews have a vas deferens gland (Kowalska-Dyrcz, 1966) that plays a key role in plug formation (Bedford et al., 1997c). However, although one shrew-like mole (Neurotrichus) has such a gland (Eadie, 1951), the other species of mole studied do not. In these, the role of the vas deferens gland seems likely to be substituted by the prominent Cowper's glands, the secretion of which forms a plug-like material when mixed with that from the seminal vesicles (Eadie, 1948a). A further unusual feature of the mole tract is the unusual castellated infolding of the epithelium of the vas deferens (Eadie, 1948b), a characteristic which, as in the small Australian rodent, Notomys alexis (Peirce and Breed, 1989), may relate to the number of spermatozoa that are accommodated in that location.

The spermatozoa of both moles and shrews display a distinct rostral extension of the acrosome typical of many Insectivora, and an unusual feature within it, the barbed form of the perforatorium. Initial studies in shrews indicate that spermatozoa depend on the presence of the cumulus oophorus for fertilization (Bedford et al., 1997a) and, in crocidurine shrews at least, this mass of cells induces a loss of the acrosome in all spermatozoa that enter it. In the absence of the usual peri-acrosomal membrane ligands, their fertilizing spermatozoa appear to attach to the zona by the barbs of the perforatorium (Bedford et al., 1997b). However, the morphology of the cumulus in moles differs from the discrete non-mucified cumulus ball of shrews. Histological sections of the ovarian follicles and the form of the newly ovulated cumulus-oocyte complex demonstrate that the mole cumulus, although rather dense, appears somewhat irregular and adheres to the ovulation stigma on the ovarian surface. Furthermore, it displays some mucification, and the outer layers could be dispersed by hyaluronidase, to which the soricid cumulus is quite insensitive. According to these characteristics, the mole cumulus is intermediate between the dense ball of cells seen in soricids, and the diffuse highly mucified cumulus of many higher mammals, which can often be completely dispersed by hyaluronidase. It is important to determine whether the mole cumulus has an essential role in fertilization, and whether fertilizing mole 
spermatozoa attach to the zona in the same way as in shrews, as their barbed perforatorium indicates. Such barbs are not detectable in higher mammals with a comparably large acrosomal rostrum, such as prosimian primates (Bedford, 1974), and some Microchiroptera (Mori, 1995; Phillips et al., 1997). However, a barbed perforatorium is present in other Insectivora, including hedgehogs (J. M. Bedford and O. B. Mock, unpublished), a golden mole (J. M. Bedford and R. T. F. Bernard, unpublished), as well as elephant shrews (Woodall, 1991) and some megabats (Rouse and Robson, 1986; Cummins et al., 1988). Finally, sections of dog spermatozoa often show the interrupted form of the perforatorium observed in the present study (J. M. Bedford, unpublished), and the study of Koehler et al. (1998) indicates that this may also be true for wolf spermatozoa.

It is also of interest to find an apparently simpler form of acrosomal matrix in mole spermatozoa. As shown in the present study, the matrix of Scalopus displays only one major component reactive to anti-hamster acrosomal matrix antibody, and primarily one major component reactive to bovine antibody. Thus, it appears simpler than the complex crossreactive polypetides of the matrix in these higher eutherians, despite their smaller acrosomes. Nonetheless, it is clear that the mole matrix is related antigenically to that in hamsters and bulls, the sequence analysis of which establishes a relationship to the intra-acrosomal SP-10 polypeptides of humans and monkeys (Herr et al., 1990a,b), foxes (Beaton et al., 1995) and mice (Liu et al., 1992). Although the function of the matrix is uncertain, it seems possible that this could assist the eutherian acrosome in binding to the zona pellucida either by stabilizing the shroud of the reacted acrosome during the secondary binding phase, or as a base from which a bound enzyme, such as acrosin, can crosslink to the zona pellucida. Whether shrew spermatozoa also have a simpler acrosomal matrix as a correlate of a barbed perforatorium is presently under investigation.

Although the numbers are small, the fact that hCG induced ovulation in Scalopus is consistent with the suggestion of Conaway (1959), based on his finding that all ovulated females were pregnant, that Scalopus is an induced ovulator. Although the penis in these and some other moles, and in crocidurine shrews, is decorated with the spines that are common among induced ovulators (see Milligan, 1982), spines also occur among others that are not, for example Australian rodents (Breed, 1986). Moreover, some induced ovulators have no penile spines; they are not detectable in rabbits and in soricine shrews (Blarina, Cryptotis, several Sorex sp.: Pearson, 1944; O. B. Mock, unpublished; P. Stockley, personal communication). Similarly, the African hedgehog (Atelerix albiventris) has no penile spines, yet ovulates in response to hCG and mating (O. B. Mock and J. M. Bedford, unpublished).

Finally, moles present an interesting paradigm for efforts to analyse the determinants of sperm production in mammals. The ampulla of the oviduct has the modest dimensions associated with the ovulation of a dense nonexpanded cumulus and, by inference from the situation in shrews, it seems likely that the differentiated crypts that extend throughout the oviductal ampulla in Scalopus and Condylura are populated by spermatozoa before fertilization.
In at least two marsupial families, crypts in the isthmus of the oviduct perform a true storage function and appear to be associated with a reduced sperm production by the male, implying that their oviductal crypts may have been a determinant of the low sperm production typical of these marsupial groups (Bedford et al., 1984; Bedford, 1999). Although oviductal crypts in shrews probably have a different role involving regulation rather than storage of spermatozoa (Bedford et al., 1997c), the fact that these animals ejaculate relatively few spermatozoa, and house relatively few spermatozoa in the oviduct indicates that such crypts might also be a functional correlate of low numbers of spermatozoa in Insectivora. However, as shown in the present study, these crypts are also prominent in moles in which the number of spermatozoa stored in the male tract is paradoxically very large (Table 1). For example, the large Katmandu strain of the musk shrew, Suncus murinus (male body weight approximately 80-125 g) ejaculates only about $1 \times 10^{6}$ spermatozoa, and only approximately $10 \times 10^{6}$ spermatozoa are housed in the epididymides compared with about $3000 \times 10^{6}$ in the approximately $50 \mathrm{~g}$ male star-nose mole. This disparity appears to weaken the proposal that the presence of oviductal crypts may be functionally linked to low sperm production rates in these primitive eutherians. However, since both are induced ovulators and lead semisolitary lives, it does leave a major question as to the basis for the large difference in sperm production between shrews and moles.

The authors are greatly indebted to Ken Catania, Department of Psychology, Vanderbilt University, for catching the live Condylura and Scalopus, to Gil Dryden for providing the Scalopus caught in spear traps, and to Lee Cohen-Gould of the Electron Microscopy Unit of Cornell Medical College for her help. Supported in part by grants HD 20419 (G. E. Olson) and EPA CR823734010 (O. B. Mock).

\section{References}

Beaton S, Have ten J, Cleary A and Bradley MP (1995) Cloning and partial characterization of the cDNA encoding the fox sperm protein FSA-Acr.1 with similarities to the SP-10 antigen Molecular Reproduction and Development 40 242-252

Bedford JM (1974) Biology of primate spermatozoa. In Contributions to Primatology pp 97-139 Ed. WP Luckett. S. Karger, Basel

Bedford JM (1991) The co-evolution of mammalian gametes. In A Comparative Overview of Mammalian Fertilization pp 3-35 Eds BS Dunbar and MG O'Rand. Plenum Press, New York

Bedford JM (1999) The implications of unusual sperm/female relationships in mammals. In The Male Gamete: From Basic Knowledge to Clinical Applications pp 81-92 Ed. C Gagnon. Cache River Press, Vienna, Illinois

Bedford JM, Rodger JC and Breed WG (1984) Why so many mammalian spermatozoa - a clue from marsupials? Proceedings of the Royal Society $B$ London 221 221-223

Bedford JM, Mock OB and Phillips DM (1997a) The unusual ampullary sperm crypts, and behaviour and role of the cumulus oophorus in the oviduct of the Least Shrew, Cryptotis parva. Biology of Reproduction 56 1255-1267

Bedford JM, Mori T and Oda S (1997b) The unusual state of the cumulus oophorus and of sperm behaviour within it, in the musk shrew, Suncus murinus. Journal of Reproduction and Fertility 110 127-134

Bedford JM, Mori T and Oda S (1997c) Ovulation induction and gamete transport in the female tract of the musk shrew, Suncus murinus. Journal of Reproduction and Fertility 110 115-125

Bedford JM, Bernard RTF and Baxter RM (1998) The 'hybrid' character of the 
gametes and reproductive tracts of the African shrew, Myosorex varius, supports its classification in the Crocidosoricinae Journal of Reproduction and Fertility 112 165-173

Bradford MM (1976) A rapid and sensitive method for the quantitation of microgram quantities of protein utilizing the principle of protein-dye binding Analytical Biochemistry 72 248-254

Breed WG (1986) Comparative morphology and evolution of the male reproductive tract in the Australian hydromyine rodents (Muridae) Journal of Zoology London 209 607-629

Castellani-Ceresa L, Cotelli F, Lora-Lamia C and Berruti G (1980) The spermatozoa of Talpa europaea with particular reference to the acrosome region Journal of Ultrastructural Research 72 112-118

Catania KC (1995) Innervation of the sensory organs on the snout of the starnosed mole Journal of Comparative Neurology 351 536-548

Conaway CH (1959) The reproductive cycle of the Eastern Mole Journat of Mammalogy 40 180-194

Cummins JM, Robson SK and Rouse WG (1988) The acrosome reaction in spermatozoa of the grey-headed flying fox (Pteropus potiocephalus: Chiroptera) exposes barbed subacrosomal material Gamete Research 21 11-22

Deanesly R (1966) Observations on reproduction in the mole, Talpa europaea. In Comparative Biology of Reproduction in Mammals pp 387-402 Ed. IW Rowlands. Academic Press, New York

Eadie WR (1948a) Corpora amylacea in the prostatic secretion and experiments on the formation of a copulatory plug in some insectivores Anatomical Record 102 259-271

Eadie WR (1948b) The male accessory reproductive glands of Condylura with notes on a unique prostatic secretion Anatomical Record 101 59-79

Eadie WR (1951) A comparative study of male accessory genital glands of Neurotrichus. Journal of Mammalogy 32 36-43

Hamilton WJ (1931) Habits of the star-nosed mole, Condylura cristata. Journal of Mammalogy 12 345-355

Hayssen S, van Tienhoven A and van Tienhoven A (1993) Asdell's Patterns of Mammalian Reproduction. Comstock Publishing, Ithaca, NewYork

Herr JC, Flickinger CJ, Homyk M, Klotz K and John E (1990a) Biochemical and morphological characterization of the intra-acrosomal antigen SP-10 from human sperm Biology of Reproduction 42 181-193

Herr JC, Wright RM, John E, Foster J, Kays T and Flickinger CJ (1990b) Identification of human acrosomal antigen SP-10 in primates and pigs Biology of Reproduction 42 377-382

Kenagy GJ and Trombulak SC (1986) Size and function of mammalian testes in relation to body size Journal of Mammalogy 67 1-22

Koehler JK, Platz CC, Jr, Waddell W, Jones MH and Behrns S (1998) Semen parameters and electron microscope observations of spermatozoa of the red wolf, Canis rufus. Journal of Reproduction and Fertility 114 95-101

Kowalska-Dyrcz A (1966) A comparative study of the male genital tract in some species of shrews Acta Theriologica (Bialowieza) 11 71-127

Laemmli UK (1970) Cleavage of structural proteins during the assembly of the head of Bacteriophage T4 Nature (London) 227 680-685

Liu M-S, Aebersold R, Fann C-H and Lee C-YG (1992) Molecular and developmental studies of a sperm acrosome antigen recognized by HS-63 monoclonal antibody Biology of Reproduction 46 937-948

McKenna MC and Bell SK (1997) Classification of Mammals Above the Species Level Columbia University Press, New York
Matthews LH (1935) The oestrous cycle and intersexuality in the female mole (Talpa europaea Linn.) Proceedings of the Zoological Society of London 1935 347-383

Milligan SR (1982) Induced ovulation in mammals Oxford Reviews of Reproductive Biology 4 1-46

Mori T (1995) Comparative sperm structure in bats (Chiroptera): some taxonomic and adaptive implications. In Advances in Spermatozoal Phylogeny and Taxonomy Vol. 166 pp 421-429 Eds BGM Jamieson, J Ausio and J-L Justine. Memoires du Museum National d'Histoire Naturelle, Paris

Mossman H and Duke KL (1973) Comparative Morphology of the Mammalian Ovary University of Wisconsin Press, Madison, Wisconsin

Olson GE, Winfrey VP, Neff JC, Lukas TJ and Nagdas SK (1997) An antigenically related polypetide family is a major structural constituent of a stable acrosomal matrix assembly in bovine spermatozoa Biology of Reproduction 57 325-334

Olson GE, Winfrey VP and Nagdas SK (1998) Acrosome biogenesis in the hamster: ultrastructurally distinct matrix regions are assembled from a common precursor polypeptide Biology of Reproduction 58 361-370

Pearson OP (1944) Reproduction in the shrew (Blarina brevicauda Say) American Journal of Anatomy 75 39-93

Peirce EJ and Breed WG (1989) Light microscopical structure of the excurrent ducts and distribution of spermatozoa in the Australian rodents $P_{\text {seudomys }}$ australis and Notomys alexis. Journal of Anatomy 162 195-213

Phillips DM and Bedford JM (1985) Unusual features of sperm ultrastructure in the musk shrew Suncus murinus. Journal of Experimental Zoology 235 119-126

Phillips DM, Rasweiler JJ, IV and Muradali F (1997) Giant, accordioned sperm acrosomes of the greater bulldog bat, Noctilio leporinus. Molecular Reproduction and Development 48 90-94

Racey PA (1978) Seasonal changes in testosterone levels and androgendependent organs in male moles (Talpa europaea) Journal of Reproduction and Fertility $\mathbf{5 2}$ 195-200

Rouse GW and Robson SK (1986) An ultrastructural study of megachiropteran (Mammalia: Chiroptera) spermatozoa: implications for chiropteran phylogeny Journal of Submicroscopical Cytology 18 137-152

Springer MS, Cleve GC, Madsen O, de Jong WW, Waddell, Amrine HM and Stanhope MJ (1997) Endemic African mammals shake the phylogenetic tree Nature (London) 388 61-64

Stanhope MJ, Waddell VG, Madsen O, de Jong WW, Hedges SB, Cleven GC, Kao D and Springer MS (1998) Molecular evidence for multiple origins of Insectivora and for a new order of endemic African insectivore mammals Proceedings National Academy of Sciences USA 95 9967-9972

Suzuki F and Racey PA (1976) Fine structural changes in the epididymal epithelium of moles (Talpa europaea) throughout the year fournal of Reproduction and Fertility 47 47-54

Towbin H and Gordon J (1984) Immunoblotting and dot immunoblotting current status and outlook Journal of Immunological Methods 72313-340

Whitworth DJ, Licht P, Racey PA and Glickman SE (1999) Testis-like steroidogenesis in the ovotestis of the European mole (Talpa europaea) Biology of Reproduction 60 413-418

Woodall PF (1991) An ultrastructural study of the spermatozoa of elephant shrews (Mammalia: Macroscelidea) and its phylogenetic implications Journal of Submicroscopical Cytology 23 47-58 